area ratio were also estimated in order to find out the relationship of the difference by the fixation and the mobility of tooth. The results were

1. Occlusal force, occlusal loading ratio and occlusal area ratio of high mobile tooth group showed statistically significant increase after fixation than that of no/low mobile tooth group.

2. Occlusal area of high mobile tooth group showed a tendency of increase after fixation than that of no/low mobile tooth group.

\title{
2. 歯周組織破壊と歯列の変化との関係
}

萩原 正剛（九歯大·保存 2）

本研究は，ヒトの口腔内にて，頬舌的な方向への歯の移動に歯周疾患による歯周組織破壊が影響しているかという 点を, 明らかにすることを目的として行った。柬周病患者 62 名の 1538 歯を対象とし，歯周組織破壊度のパラメー夕 として, 初診時 PPD, PALを用いた. 次に, 初診時診査用模型の咬合面観をあとに, コンピュータにて各模型の仮 想歯列弓を設定した. 仮想歯列弓より逸脱した変位歯群のPPD, PAL と, 変位方向との関係について検討した. 結 果, 㚘側への変位群は, 㚘側に比べ舌·口蓋側で有意な歯周組織破壊を認め, 舌側への変位群は, 㚘側に歯周組織破 壊の傾向を認めた，以上より，歯周疾患による歯周組織破壊が, 頬舌方向への歯の変位を生じさせる，一要因である ことが示唆された。

\section{Relationship between periodontal tissue destruction and alteration of dentitions}

Seigo Hagiwara (Department of Periodontology and Endodontology, Kyushu Dental College)

The present study was performed to investigate the influence of periodontal tissue destruction for tooth migration. Sixty-two periodontitis patients including 1538 teeth were employed for this study. Periodontal parameters including probing pocket depth and probing attachment level, and study cast impressions were taken at the baseline examination. Tooth migration was defined when more than $2 \mathrm{~mm}$ of displacement from ideal dentition was existed. Buccally migrated teeth showed more periodontal tissue breakdown on lingual aspect, and lingually migrated teeth in upper and lower anterior region and upper posterior region showed more breakdown on buccal aspect, that is in coincidence of our previous animal experiment.

\section{3．マウス歯胚における血管内皮増殖因子（VEGF）とVEGFレセプター2（VEGFR2/Flk-1）の局在 \\ 尾川 幸雄（九歯大·保存 1 )}

血管内皮增殖因子（VEGF）とVEGFレセプター2（VEGFR2/Flk-1）は個体発生に抢ける主要な血管新生因子 である. 今回の研究ではマウス歯胚発生における VEGF と Flk-1の局在を免疫組織化学的に観察した. 臼歯の蕾状期 と帽状期では VEGF と Flk-1は主にェナメル器構成細胞に局在していた．VEGF/Flk-1の両方に陽性な細胞はエナ メル器と凝集している歯乳頭に観察された。鐘状期前期ではVEGF と Flk-1の局在は前エナメル芽細胞と前象牙芽 細胞に集中しており，鐘状期後期ではVEGF/Flk-1の局在は分化した象牙芽細胞とエナメル芽細胞に認められた. 㐘 根形成期の歯根膜においても VEGF/Flk-1の両方に陽性な細胞が歯根象牙質に接しているのが観察された．萌出前 の切歯歯胚では, VEGF と Flk-1は前エナメル芽細胞を含む内エナメル上皮, および前象牙芽細胞を含む歯乳頭細胞 に一過性に局在していた。これらの結果はVEGF と Flk-1は歯胚の発生段階に打けるエナメル芽細胞と象牙芽細胞 の分化·成熟に重要な役割を果たしていることを示唆している.

\section{Localizations of Vascular Endothelial Growth Factor (VEGF) and VEGF Receptor 2 (VEGFR2/Flk-1) during Mouse Tooth Development}

Yukio Ogawa (Department of Operative Dentistry and Endodontics)

Vascular endothelial growth factor (VEGF) and VEGF receptor 2 (VEGFR2/Flk-1) are major 